\title{
Perspektif Orang Tua dan Guru Mengenai Bullying Pada Anak Usia Dini di Taman Kanak-kanak
}

\author{
Lestari Widaningtyas ${ }^{\circledR}{ }^{\bowtie}$, Sugito ${ }^{1}$ \\ Pendidikan Anak Usia Dini, Universitas Negeri Yogyakarta, Indonesia(1) \\ DOI: $\underline{10.31004 / \text { obsesi.v6i4.2313 }}$
}

\begin{abstract}
Abstrak
Bullying dapat dilakukan semua orang termasuk anak usia dini. Bullying yang tidak disadari atau hanya dibiarkan dapat menimbulkan dampak negatif bagi perkembangan sosial, mental, dan fisik anak. Penelitian ini bertujuan untuk mendeskripsikan perspektif orang tua dan guru mengenai bullying pada anak usia dini di taman kanak-kanak. Menggunakan pendekatan kualitatif dengan jenis penelitian studi kasus. Pengumpulan data menggunakan wawancara, observasi, dan dokumentasi. Pemilihan responden menggunakan purposive sampling. Analisis data yang digunakan adalah model analisis interaktif Miles dan Huberman. Hasil penelitian menunjukkan adanya beragam perspektif orang tua dan guru mengenai kecenderungan perilaku bullying pada anak usia dini. Perbedaan perspektif ini dipengaruhi oleh faktor tingkat pendidikan, pengalaman, perbedaan persepsi, dan kurangnya informasi. Bentuk bullying yang terjadi pada anak usia dini antara lain meninju perut, memukul, menjegal, mengambil dan merebut makanan, mengejek fisik, mengejek sifat, mengejek hasil karya, mengejek kemampuan, mengejek nama, pengucilan, serta penghasutan. Orang tua dan guru di TK IPPA Nurul Haq telah melakukan berbagai upaya pencegahan dan penanganan terhadap bullying serta tindakan kekerasan yang dilakukan oleh anak usia dini.
\end{abstract}

Kata Kunci: perspektif orang tua dan guru; bullying; anak usia dini

\begin{abstract}
Bullying can be done by everyone, including early childhood. Bullying that is not realized or just ignored can have a negative impact on children's social, mental, and physical development. This study aimed to describe the perspectives of parents and teachers regarding bullying in early childhood in kindergarten. The research uses a qualitative approach with the type of case study. Data was collected using interview, observation, and documentation. The selection of respondents using purposive sampling. Analysis of the data used is the interactive analysis model of Miles and Huberman. The results of the study show There are various perspectives from parents and teachers regarding the tendency of bullying behavior in early childhood. This difference in perspective is influenced by many factors such as level of education, experience, differences in perception, and lack of information. The forms of bullying that occur include punching the stomach, hitting, tripping, taking and snatching food, physical mocking, mocking nature, mocking work, mocking abilities, mocking names, ostracism, and incitement. Parents and teachers at IPPA Nurul Haq Kindergarten have made various efforts to prevent and deal with bullying and acts of violence committed by early childhood. Different perspectives have an influence on awareness and contribution in preventing and dealing with bullying. Teachers can provide information, discuss, and cooperate with parents in preventing and dealing with bullying in schools.
\end{abstract}

Keywords: parents and teacher's perspective, bullying, early childhood

Copyright (c) 2022 Lestari Widaningtyas, Sugito

$\triangle$ Corresponding author :

Email Address : lestariwidaningtyas.2019@student.uny.ac.id (Yogyakarta, Indonesia)

Received 19 November 2021, Accepted 8 February 2022, Published 8 February 2022 


\section{PENDAHULUAN}

Permasalahan bullying memang sudah sering terjadi; namun khususnya pada anak usia dini, hal ini masih menjadi perdebatan. Sejak usia dini, anak dilatih untuk membangun hubungan pertemanan dengan teman sebayanya. Ketika anak bermain dengan teman, tak jarang kita menemukan adanya anak yang berperilaku agresif seperti melakukan agresi fisik dan verbal. Dey Putri et al (2020) menyatakan apabila perilaku agresif ini dibiarkan dan selalu diizinkan, maka dapat menimbulkan bullying pada anak usia dini. Bullying adalah perilaku sengaja dan berulang yang dilakukan seseorang atau kelompok yang merasa memiliki kekuatan lebih, sehingga menimbulkan ketidakseimbangan kekuatan dan dampak negatif secara langsung maupun tidak langsung (Douvlos, 2019; Mahriza et al., 2020; Reunamo et al., 2015; Storey \& Slaby, 2013; Vlachou et al., 2013). Bullying berbeda dengan perkelahian atau konflik interpersonal, Olweus (1994) menyatakan sebuah perilaku dikategorikan bullying apabila memenuhi tiga kriteria, yaitu dilakukan (1) sengaja, (2) berulang kali, dan (3) menimbulkan ketidakseimbangan kekuatan.

Penelitian beberapa tahun terakhir menunjukkan bahwa anak usia dini dapat terlibat bullying, seperti Cameron \& Kovac (2016) di Norwegia menemukan 11\% orang tua menyatakan sering melihat bullying di antara anak-anak dan 49\% lainnya tidak pernah melihat; kemudian Kirves \& Sajaniemi (2012) di Finlandia juga menemukan 12,6\% anak usia 3-6 tahun di lembaga penitipan anak usia dini terlibat bullying. Penemuan tersebut tidak jauh berbeda dengan di Indonesia; penelitian Hartati et al (2020) kepada 165 anak usia 4-6 tahun di Jakarta Timur menemukan 35\% anak telah melakukan bullying dalam bentuk mencubit, memukul, mendorong, meninju, menyembunyikan mainan, merusak mainan teman, meludah, mengancam, mengejek, menggoda, dan berbicara kasar. Bullying pada anak usia dini juga sudah terjadi di Yogyakarta, namun penelitian yang membahas jumlah kasus tersebut belum ada; akan tetapi Rahayu et al (2020) di Yogyakarta telah menemukan bahwa bullying terjadi di taman kanak-kanak karena kondisi lingkungan yang kurang kondusif yaitu kurangnya pengawasan saat anak-anak aktif bermain dan kurangnya pengetahuan guru mengenai tanda terjadinya bullying. Selanjutnya penelitian tentang jumlah kasus bullying di Kulon Progo juga belum ada, namun dari observasi yang telah dilakukan di beberapa TK di Kulon Progo ditemukan beberapa bentuk bullying yang dilakukan anak usia dini seperti mengejek fisik, memukul, menendang, mencubit, mendorong, merebut bekal, pengucilan, dan penyebaran desas-desus.

Bullying disebabkan oleh faktor internal dan eksternal. Faktor internal seperti temperamen dan keterampilan sosiokognitif. Olweus (1996) mengemukakan anak yang bertemperamen aktif dan cenderung menyelesaikan masalah dengan kepala panas lebih berkembang menjadi anak yang agresif. Selanjutnya Vlachou et al (2014) menyatakan keterampilan sosiokognitif juga mempengaruhi bullying, yaitu ketika anak melakukan interaksi maka anak perlu memahami bahwa orang lain bisa memiliki pendapat, pandangan, dan perasaan yang berbeda, akan tetapi tidak semua anak bisa melakukan hal ini. Berikutnya faktor eksternal pertama yaitu keluarga. DeVooght, et al (2015) menjelaskan anak yang mampu membangun kelekatan aman dengan orang tua lebih mampu mengembangkan keterampilan regulasi emosi, perilaku prososial, empati, percaya diri, pemecahan masalah, serta menciptakan hubungan timbal balik; sedangkan anak yang tidak mampu membangun kelekatan aman akan kesulitan mengelola perasaan dan sulit mengembangkan hubungan positif sehingga cenderung bermusuhan dan melakukan agresi kepada teman sebayanya. Selanjutnya, orang tua dengan pola pengasuhan yang tegas, ditandai penggunaan hukuman fisik, kekerasan, dan kurangnya interaksi positif dapat menyebabkan peningkatan perilaku agresi. Selain kelekatan dan pengasuhan, Jansen et al (2012) menyebutkan adanya korelasi yang kuat status ekonomi dengan bullying, yang mana di dalam keluarga status ekomi rendah tidak ditemukan batasan mengenai perilaku anak. Orang tua pun kurang melakukan pengawasan dan memberi teladan yang baik bagi anak. Berikutnya faktor ke dua yaitu lingkungan; anak tinggal di lingkungan masyarakat yang terdiri dari berbagai orang dengan 
karakteristik beragam. Seorang anak dapat mempelajari perilaku melalui observasi dan modelling terhadap orang-orang di sekitarnya termasuk perilaku positif dan negatif. Perilaku negatif yang dilihat anak dapat dipelajari dan diinternalisasi, sehingga anak akan menganggap perilaku negatif tersebut sebagai perilaku yang disetujui lingkungannya, sehingga apabila anak mencontohnya maka ini bukanlah hal yang dilarang (Humphrey, 2013). Kemudian faktor ketiga adalah media, Zimmerman et al (2005) menemukan korelasi antara lamanya waktu anak menonton televisi saat usia 4 tahun dengan perilaku bullying. Televisi dikaitkan dengan peningkatan agresi yang dilakukan anak, hal ini dikarenakan $60 \%$ program televisi mengandung kekerasan. Selain kekerasan, terdapat juga program yang menayangkan perilaku antisosial yang juga dilihat dan dicontoh anak untuk melakukan bullying verbal.

Apabila bullying terjadi dan dibiarkan, maka dapat menimbulkan dampak negatif bagi perkembangan sosial, mental, dan fisik anak. Dampak tidak hanya dirasakan korban, tetapi juga pelaku dan bystander (Kirves \& Sajaniemi, 2012; Karatas \& Ozturk, 2011; Humphrey, 2013; Storey \& Slaby, 2013; Saracho, 2016). Oleh karena itu, dibutuhkan upaya untuk mencegah dan menangani bullying. Terdapat persetujuan dari guru dan orang tua bahwa dalam mengintervensi bullying diperlukan kerja sama dari orang tua, guru, masyarakat, maupun anak yang terlibat (Mishna et al., 2006). Namun, fakta di lapangan menemukan perbedaan pandangan orang tua dan guru mengenai bullying pada anak usia dini. Perbedaan pertama dapat dipengaruhi persepsinya. Sebagian orang tua percaya bullying ditemukan pada anak usia dini, namun sebagian lainnya tidak percaya bahkan menyangkal (Cameron \& Kovac, 2016). Survei awal oleh peneliti menunjukkan 16,7\% orang tua dan guru memilih "bullying tidak terjadi di taman kanak-kanak"; dengan alasan anak masih TK, belum bisa melakukan bullying terencana, dan "kurang kerjaan" jika anak TK membully. Lalu beberapa orang menggambarkan bullying sebagai bagian perkembangan (Mishna et al., 2006). Sims-Schouten (2015) juga menemukan praktisi dan orang tua yang memandang anak kecil tidak mengerti dan belum mampu membuat penilaian tentang perilaku benar dan salah. Berikutnya, Humphrey \& Crisp (2008) menyebutkan ada kesulitan dalam membedakan perilaku bullying dan non bullying, sehingga muncul keraguan dalam memberi label dan memilih menggunakan istilah perilaku "tidak pantas".

Faktor kedua, Mishna et al (2006) mengemukakan pengalaman di masa lalu dapat mempengaruhi pemahaman tentang bullying. Orang dewasa yang pernah dibully maupun orang tua yang anaknya pernah menjadi korban akan lebih sensitif terhadap bullying dibandingkan yang belum pernah mengalami bullying. Faktor ketiga yaitu perbedaan tingkat pendidikan, dimana seseorang yang berpendidikan tinggi seperti sarjana memiliki pemahaman yang lebih luas dibanding seseorang yang berpendidikan rendah (Bili, 2021). Pandangan mengenai bullying tidak sekedar kenakalan dan orang-orang yang berpendidikan tinggi berusaha mengakses informasi serta turut serta dalam mengatasi bullying. Faktor keempat, peningkatan usia seseorang berhubungan dengan perhatian terhadap masalah bullying pada usia dini tidak beralasan (Cameron \& Kovac, 2016). Ayah yang usianya lebih tua dan berpendidikan rendah lebih sering dikaitkan dengan kecenderungan mengecilkan masalah bullying di prasekolah. Ayah dinilai kurang bersimpati terhadap korban. Faktor kelima, perbedaan budaya (Lee, 2020). Menurut Smith (2019), sebagian besar penelitian bullying dan viktimisasi terdapat dalam dimensi individualisme-kolektivisme. Beberapa peneliti menyatakan budaya individualisme berhubungan dengan tingkat agresi yang lebih tinggi dibandingkan kolektivisme. Budaya kolektivisme menekankan norma sosial yang ketat, keharmonisan, dan hubungan interpersonal yang positif. Oleh karena itu, sejak dini anak diajarkan untuk mengendalikan perilaku agresif, perilaku impulsif, dan amarah. Faktor keenam, kurangnya informasi. Mishna et al (2006) mengungkapkan informasi mengenai bullying yang kurang tersedia, ketidaktahuan cara intervensi, dan kurangnya pelatihan serta kebijakan intervensi bullying dapat mempengaruhi pola pikir dan sudut pandang seseorang. Seperti pendapat Kallestad \& Olweus (2003), sebuah informasi dapat mempengaruhi cara 
individu dalam merespon permasalahan, sehinga kekurangan informasi dapat mengakibatkan seseorang menjadi tidak tahu dan kurang menyadari bullying yang terjadi.

Perspektif yang berbeda mengenai bullying yang terjadi dan dilakukan anak usia dini memberikan pengaruh yang berbeda juga terhadap sikap dan respon orang tua serta guru dalam mensikapi bullying yang terjadi. Penelitian sebelumnya mengenai bullying pada anak usia dini cenderung menggunakan pendekatan kuantitatif; namun ada juga yang menggunakan pendekatan kualitatif dengan menggunakan indikator pendidikan orang tua untuk melihat pemahaman orang tua mengenai perilaku bullying anak. Sedangkan pada penelitian kali ini peneliti menggunakan pendekatan kualitatif, karena melalui pendekatan ini peneliti dapat memperoleh informasi yang mendalam berkaitan dengan perspektif orang tua dan guru mengenai bullying pada anak usia dini. Faktor yang dapat mempengaruhi perspektif tersebut, tidak hanya dilihat dari tingkat pendidikan orang tua dan guru saja, namun juga melihat faktor lainnya seperti usia, pekerjaan, pengalaman dari orang tua dan guru. Penelitian mengenai kecenderungan perilaku bullying khususnya pada anak usia dini di Kulon Progo belum pernah dilakukan. Oleh karena itu, peneliti melakukan penelitian ini untuk mendeskripsikan perspektif orang tua dan guru mengenai kecenderungan perilaku bullying pada anak usia dini di salah satu taman kanak-kanak

\section{METODOLOGI}

Penelitian menggunakan pendekatan kualitatif dengan jenis studi kasus. Desain studi kasus yang digunakan yaitu studi kasus tunggal; sehingga peneliti dapat mengeksplorasi dan mendeskripsikan secara mendalam mengenai permasalahan bullying. Penelitian dilaksanakan di TK IPPA Nurul Haq yang beralamatkan di Jalan KRT. Kertodiningrat 24, Karangtengah Kidul, Margosari, Pengasih, Kulon Progo. Pelaksanaan penelitian pada bulan Mei-Juli 2021. Pemilihan TK IPPA Nurul Haq sebagai lokasi penelitian dikarenakan wali murid di TK IPPA Nurul Haq terdiri dari berbagai latar belakang sosial dengan tingkat pendidikan, usia, dan pekerjaan yang berbeda. Guru pun juga terdiri dari berbagai lulusan program studi dan usia yang berbeda; sehingga adanya perbedaan tersebut diduga dapat mempengaruhi perspektif mereka terhadap bullying pada anak usia dini.

Pengumpulan data dilakukan melalui wawancara semi terstruktur, observasi partisipasi pasif, serta dokumentasi berupa dokumen sekolah, rekaman, video, dan foto. Instrumen penelitian adalah peneliti sendiri dengan menggunakan pedoman. Data penelitian terdiri data primer dan sekunder. Data primer diperoleh langsung melalui wawancara dan observasi kepada enam orang tua dan lima guru. Pemilihan responden dilakukan dengan purposive sampling, peneliti memilih responden berdasarkan tingkat pendidikan, pekerjaan, dan usia. Sebelum wawancara, peneliti meminta izin kepada orang tua dan guru terlebih dahulu secara lisan tanpa menggunakan lembar informed consent. Setelah diizinkan, wawancara dilaksanakan di sekolah dan rumah responden. Pertanyaan wawancara mencakup beberapa sub aspek yang disajikan dalam tabel 1. Sedangkan pedoman observasi partisipasi pasif akan disajikan pada tabel 2.

Selanjutnya data sekunder adalah dokumen sekolah berupa rencana pelaksanaan pembelajaran harian (RPPH); tata tertib sekolah yang berisi anak-anak diwajibkan bersikap ramah dan sopan kepada guru, teman, dan karyawan, penerapan " $5 S^{\prime}$ " (senyum, salam, sapa, sopan, dan santun), serta pembiasaan budaya "TOMAT" (tolong, maaf, dan terima kasih); SOP mengenai penyambutan yang dilakukan guru ketika anak datang ke sekolah, pijakan sebelum main, dan selama main; di dukung catatan lapangan; transkrip wawancara; dan rekaman. Berikutnya, keabsahan data diuji dengan triangulasi. Triangulasi yang digunakan yaitu check, check-recheck, dan cross-check. Analisis data yang digunakan adalah model analisis interaktif Miles dan Huberman. Model Miles dan Huberman memiliki beberapa langkah, antara lain pengumpulan data, kondensasi data, penyajian data, dan penggambaran data/verifikasi (Miles et al., 2014). Tahapan penelitian secara ringkas disajikan pada gambar 1. 
Tabel 1. Kisi-kisi Pedoman Wawancara

\begin{tabular}{|c|c|c|}
\hline No & Aspek & Sub Aspek \\
\hline 1 & $\begin{array}{l}\text { Perspektif } \\
\text { mengenai bullying }\end{array}$ & $\begin{array}{l}\text { Bagaimana pemahaman tentang bullying? } \\
\text { Bagaimana pandangan terhadap kecenderungan perilaku bullying } \\
\text { pada anak usia dini? } \\
\text { Faktor apa vang mempengaruhi pandangan? }\end{array}$ \\
\hline 2 & Bentuk bullying & $\begin{array}{l}\text { Apa bentuk bullying yang terjadi atau ditemukan? } \\
\text { Bagaimana intensitas terjadinya bullying? }\end{array}$ \\
\hline 3 & $\begin{array}{l}\text { Upaya pencegahan } \\
\text { dan penanganan }\end{array}$ & $\begin{array}{l}\text { Bagaimana upaya yang dilakukan untuk pencegahan bullying? } \\
\text { Bagaiaman upaya yang dilakukan untuk penanganan bullying? }\end{array}$ \\
\hline
\end{tabular}

Tabel 2. Kisi-kisi Pedoman Observasi

\begin{tabular}{cll}
\hline No & \multicolumn{1}{c}{ Aspek } & \multicolumn{1}{c}{ Sub Aspek } \\
\hline 1 & Bentuk bullying & Bentuk bullying yang terjadi Perilaku anak \\
2 & $\begin{array}{l}\text { Upaya pencegahan } \\
\text { dan penanganan }\end{array}$ & $\begin{array}{l}\text { Upaya pencegahan yang diajarkan } \\
\text { Upaya penanganan yang diajarkan }\end{array}$ \\
\hline
\end{tabular}

Bullying yang tidak disadari terjadi di TK
Menentukan lokasi penelitian dan subjek penelitian
Pengumpulan Data

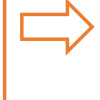$$
\text { Pengumpulan Data }
$$

Penarikan kesimpulan perspektif orang tua dan guru mengenai bullying pada anak usia dini
Pembahasan Temuan Penelitian dengan Teori yang Ada

\section{Gambar 1. Tahapan Penelitian}

\section{HASIL DAN PEMBAHASAN}

Berikut ini akan dipaparkan hasil penelitian yang telah peneliti dapatkan saat pengumpulan data. Hasil penelitian ini diperoleh dari enam orang tua yaitu HK, SS, SP, MFH, TOH, dan SMN serta lima guru yaitu SB, BAC, AAA, IU, dan SPD. Beberapa hal yang akan dipaparkan meliputi perspektif orang tua dan guru mengenai kecenderungan perilaku bullying pada anak usia dini, bentuk bullying berdasarkan perspektif orang tua dan guru, serta upaya pencegahan dan penanganan yang dilakukan orang tua dan guru terhadap bullying pada anak usia dini.

\section{Perspektif Orang Tua dan Guru Mengenai Kecenderungan Perilaku Bullying pada Anak Usia Dini}

Bullying dapat terjadi pada siapa saja tanpa memandang usia (Zakiyah et al., 2017). Hasil penelitian terdahulu yang peneliti paparkan di pendahuluan telah memperlihatkan bahwa anak usia dini sudah dapat terlibat dalam bullying. Namun dalam penelitian ini, peneliti menemukan hasil yang berbeda dengan penelitian tersebut, yaitu adanya perbedaan perspektif orang tua dan guru berkaitan dengan kecenderungan perilaku bullying pada anak usia dini. Keberagaman perspektif dipengaruhi oleh berbagai faktor, yang telah dikemukakan oleh para orang tua dan guru. Berikut tabel 3 akan menyajikan perspektif orang tua dan guru mengenai kecenderungan perilaku bullying pada anak usia dini. 
Tabel 3. Perspektif Orang Tua dan Guru Kecenderungan Perilaku Bullying pada Anak Usia Dini di TK IPPA Nurul Haq

\begin{tabular}{|c|c|}
\hline Respoden & Perspektif mengenai kecenderungan bullying pada anak usia dini \\
\hline \multicolumn{2}{|l|}{ Orang Tua } \\
\hline HK & $\begin{array}{l}\text { Kalau di sekitar sini saya belum pernah melihatlah, karena anak usia dini itu kan masih } \\
\text { berpikiran kanak-kanak terus dunianya bermain jadi ya wajarlah tingkah laku anak di } \\
\text { bawah umur. }\end{array}$ \\
\hline SS & $\begin{array}{l}\text { Di sekolah sini sementara tidak tahu terjadi atau tidak, karena saya jarang mengantar } \\
\text { dan mengawasi di sekolah. Kalau pun terjadi ya paling tidak terlalu mencolok. Jadi ya } \\
\text { kalau ada mungkin skalanya kecil. }\end{array}$ \\
\hline SP & $\begin{array}{l}\text { Bullying biasanya terjadi di sekolah, kalau tatap muka kan bertemu banyak anak maka } \\
\text { mereka akan berkelompok sehingga memungkinkan munculnya satu anak yang kurang } \\
\text { disukai dalam kelompoknya. Itu kan sudah termasuk bullying, dia akan merasa rendah } \\
\text { diri tidak bisa bergaul dengan yang lain. }\end{array}$ \\
\hline MFH & $\begin{array}{l}\text { Saya belum pernah melihat, tetapi saya juga tidak akan mendramatisir kalau terjadi } \\
\text { pada anak usia dini. Bahasanya wajar saja, saya pikir dunia anak-anak seperti itu ya } \\
\text { nangis ya berkelahi. Itu ekspresinya anak-anak, sehingga ketika anak diejek ya tidak } \\
\text { apa-apa, anak berkelahi ya enggak apa-apa. } \\
\text { Kalau bullying pada anak paud menurut saya belum serius. Saya pikir bullying itu aman, } \\
\text { tapi kalau sudah remaja, dewasa itu ya memang perlu ditata. }\end{array}$ \\
\hline $\mathrm{TOH}$ & $\begin{array}{l}\text { Secara statistik mungkin ada ya di sini, tapi saya juga tidak tahu. Anak TK itu kan } \\
\text { masih kecenderungan dia untuk menjadi nakal atau tidak nakal. Dia sendiri mungkin } \\
\text { belum terlalu mengerti ya mana yang baik. }\end{array}$ \\
\hline SMN & $\begin{array}{l}\text { Bullying itu apa ya?, Kalau sama teman sebaya itu sepertinya belum pernah baik itu } \\
\text { ucapan maupun perilaku kayaknya belum pernah, ya normal-normal lah. }\end{array}$ \\
\hline \multicolumn{2}{|l|}{ Guru } \\
\hline SB & $\begin{array}{l}\text { Di kelas saya pernah terjadi bullying itu. Ada satu anak itu si A, dia tidak mau berangkat } \\
\text { sekolah karena merasa dibully sama temannya. Dia diejek sehingga anak ini merasa } \\
\text { minder dan hampir satu minggu tidak masuk sekolah. Kita di sekolah juga mengamati } \\
\text { ana yang menjadi pelaku tadi, dan ternyata memang dia sering membully temannya. } \\
\text { Selain kita mengawasi, ada anak lainnya yang juga melaporkan kepada kita. }\end{array}$ \\
\hline BAC & $\begin{array}{l}\text { Bisa sangat bisa terjadi, saya dulu saat TK juga menjadi korban bullying. Saya hampir } \\
\text { setiap hari dikucilkan dan diejek sama teman yang tergabung dalam genk. Pernah juga } \\
\text { disiram air saat bermain di perosotan. Saat sudah kerja di TK, di kelas saya juga } \\
\text { menemukan ada anak yang pendiam dan itu menjadikan dia sering diejek sama } \\
\text { temannya. Ketika istirahat itu juga ada anak yang menangis karena temannya tidak } \\
\text { mau bermain dengan dia. } \\
\text { Menurut saya, anak itu juga meniru apa yang dia lihat dari teman-temannya. Lalu saat } \\
\text { ini juga anak bisa melihat tindakan kekerasan di televisi maupun internet. Orang tua } \\
\text { kan tidak mengawasi langsung anaknya saat mereka melihat tayangan itu. }\end{array}$ \\
\hline AAA & $\begin{array}{l}\text { Anak usia dini itu bisa melakukan bullying, ya walaupun tingkatannya berbeda dengan } \\
\text { bullying yang dilakukan orang dewasa. Itu setiap harinya hampir terjadi di sekolah, saya } \\
\text { sendiri pernah melihat langsung dan juga dilapori sama anak yang terkena bullying atau } \\
\text { temannya anak yang jadi korban. Kemudian watak atau sifat anak itu kan juga berbeda } \\
\text { ya, apalagi anak usia dini itu masih mencontoh. Jadi hal ini bisa menjadikan bullying itu } \\
\text { dilakukan oleh anak. }\end{array}$ \\
\hline IU & $\begin{array}{l}\text { Tentu saja bisa terjadi pada anak usia dini, di sekolah ini sendiri juga sudah terjadi. Saya } \\
\text { sendiri pernah melihat secara langsung. Saya memperhatikan anak itu, dia secara } \\
\text { sengaja menjulurkan kakinya ke arah pintu saat temannya mau masuk ke kelas } \\
\text { sehingga temannya ini jatuh. Nah tindakannya yang disengaja itu kan sudah termasuk } \\
\text { bullying. Selain itu bisa juga dalam bentuk ucapan seperti "kamu itu enggak bisa, hasil } \\
\text { karyamu jelek". }\end{array}$ \\
\hline SPD & $\begin{array}{l}\text { Kalau bullying yang dilakukan orang dewasa ke anak ya itu bisa terjadi, tetapi kalau } \\
\text { sesama anak menurut saya itu bukan bullying melainkan tindakan spontan saja. Dia } \\
\text { terganggu atau terancam sehingga sebagai bentuk penyelamatan diri, dia melakukan } \\
\text { kekerasan atau penindasan kepada temannya, tapi ya spontan saja bukan niatnya } \\
\text { membully. }\end{array}$ \\
\hline
\end{tabular}


Berdasarkan tabel 3, terlihat tiga pandangan orang tua dan guru terkait kecenderungan perilaku bullying pada anak usia dini. Pertama, lima responden yaitu 1 orang tua (SP) dan 4 guru (SB, BAC, AAA, dan IU) meyakini serta memandang anak usia dini bisa melakukan bullying kepada teman sebayanya. SP memandang anak usia dini sangat mungkin melakukan bullying ketika mereka berinteraksi di sekolah. Interaksi yang dilakukan anak akan memunculkan kelompok-kelompok kecil. Pembentukan kelompok nantinya dapat menimbulkan adanya anak yang kurang disukai, sehingga beresiko dikucilkan dan pada akhirnya anak merasa rendah diri serta tidak dapat bergaul. SP juga memandang bullying bisa ditemukan dalam bentuk sederhana seperti mengejek. Pandangan SP diduga dipengaruhi faktor pendidikan. SP merupakan lulusan magister dan saat ini bekerja sebagai dosen. Tingkat pendidikan dan pekerjaan SP memungkinkan SP memiliki pemahaman yang lebih baik mengenai bullying serta kemampuan lebih baik dalam mengakses informasi yang berhubungan dengan perkembangan anak, permasalahan perilaku seperti bullying, dan lainnya. Ketika menjalani perkuliahannya, SP mempelajari psikologi perkembangan dan psikologi pendidikan, yang menurutnya dapat dijadikan acuan dalam menghadapi anak serta melakukan pencegahan bullying. Pandangan SP yang diduga dipengaruhi tingkat pendidikan ini sejalan dengan pendapat Bili (2021). Menurut Bili (2021), tingkat pendidikan dapat mempengaruhi cara seseorang dalam menyadari dan mensikapi bullying. Orang tua dengan pendidikan tinggi tidak akan menganggap bullying sebagai kejadian biasa, karena dapat menimbulkan efek yang begitu merugikan, mereka juga cenderung mengakses berbagai informasi terkait bullying sehingga lebih mampu mengetahui tanda-tanda bullying, menyadari, dan melakukan pencegahan terhadap bullying. Hal ini sama dengan SP, dimana SP melihat bahwa bullying ini bisa ditemukan dalam bentuk yang sederhana seperti mengejek; sehingga ejekan yang biasa ditemukan dalam keseharian anakanak tidak bisa dianggap sebagai kejadian yang biasa.

Selanjutnya, empat guru (SB, BAC, AAA, dan IU) memandang anak usia dini bisa melakukan bullying walaupun tingkatannya berbeda dengan orang dewasa. Pandangan empat guru tersebut didasarkan pada faktor pengalaman, namun pengalamannya sedikit berbeda. Seperti yang tertulis di tabel 3, SB, AAA, dan IU mengaku pernah melihat adanya siswa di kelasnya yang dibully temannya. Siswa dibully dengan cara diejek dan dijegal. Kejadian ini tidak hanya terjadi saat kegiatan pembelajaran saja. Selain pengamatan, guru juga mengetahui adanya bullying dari laporan anak dan kegiatan homevisit. Berikutnya pengalaman yang berbeda dirasakan BAC, yaitu menjadi korban bullying saat di TK. Bullying tersebut dilakukan oleh teman sekelas beliau yang juga merupakan anak usia dini. Temanteman BAC sering berkata bagian meja yang besar untuk BAC, sedangkan mereka yang kecil. BAC tidak mengetahui alasan temannya sering berkata seperti itu. BAC merasa terkucilkan setiap harinya. Selain perkataan, BAC juga pernah disiram air oleh temannya sehingga roknya basah. Kemudian setelah BAC bekerja sebagai guru di TK IPPA Nurul Haq, BAC juga menjumpai adanya anak yang sering diejek karena anak tersebut pendiam dan menyendiri di pojokan. Lalu saat istirahat, BAC juga melihat ada anak yang menangis karena temannya tidak mau mengajak bermain. Adanya pengalaman melihat bullying secara langsung dan pengalaman sebagai korban inilah yang menjadikan ke empat guru meyakini dan memandang bahwa bullying memang bisa dilakukan oleh anak usia dini. Hal ini senada dengan Mishna et al (2006) bahwa orang dewasa yang di masa lalunya pernah menjadi korban maupun pelaku bullying serta orang tua yang memiliki anak dan pernah dijadikan sebagai korban, maka orang-orang ini akan menjadi lebih sensitif dan menyadari adanya bullying dibandingkan dengan orang-orang yang sama sekali belum pernah mengalami dan menghadapi bullying.

Selain pengalaman, BAC dan AAA berpandangan bahwa anak cenderung mencontoh orang-orang di sekitarnya. Ketika anak berinteraksi dengan teman sebaya atau orang dewasa, anak dapat melihat perilaku mereka seperti perilaku baik dan tidak baik. Apa yang dilihat anak berisiko untuk ditiru. Oleh karena itu menurut ke dua guru ini, faktor 
lingkungan juga dapat mempengaruhi anak dalam melakukan bullying. Pandangan BAC dan AAA senada dengan salah satu faktor penyebab bullying yang dikemukakan Humphrey (2013) bahwa perilaku bullying pada anak usia dini dapat disebabkan dari perilaku yang dipelajari anak dengan cara melihat perilaku yang dilakukan oleh anak usia dini yang lebih tua maupun orang dewasa. Anak juga belajar bagaimana teman sebaya dan orang dewasa di sekitarnya memberi persetujuan terhadap perilakunya. Apabila perilaku disetujui, maka anak akan tetap melakukannya. Selanjutnya faktor lingkungan ini juga sesuai dengan teori Bronfenbrenner yaitu teori ekologi, bahwa bullying adalah fenomena kompleks yang melibatkan berbagai interaksi, salah satunya adalah "mikrosistem". Mikrosistem adalah lingkungan dimana anak dapat berinteraksi secara langsung seperti rumah, sekolah, dan grup pertemanan; dari interaksi ini memungkinkan anak untuk melihat dan mendengar sesuatu yang kemudian itu bisa dicontoh oleh anak.

Berikutnya, BAC dan SP menyadari resiko "mencontoh" tidak hanya dari lingkungan. Televisi, hp, dan internet turut mempengaruhi anak dalam melakukan bullying. Apalagi sekarang, orang tua cenderung memberi hp dan remot televisi kepada anak agar tidak rewel. Namun selama anak menonton media, tidak semua orang tua melakukan pengawasan dan kontrol terhadap tayangan yang dilihat, padahal tindakan ini sangat perlu dilakukan. Hal ini sejalan dengan Zimmerman et al (2005) bahwa ada korelasi antara intensitas waktu anak menonton televisi pada usia 4 tahun dengan perilaku bullying di sekolah. Meskipun tayangan tidak berisi kekerasan, namun dalam tayangan televisi juga terdapat contoh perilaku anti sosial yang dapat dilihat dan dicontoh anak untuk melakukan bullying verbal.

Kedua, dua responden yaitu SS dan TOH ragu-ragu dalam menjawab kecenderungan perilaku bullying pada anak usia dini. SS dan TOH sama-sama belum pernah melihat secara langsung bullying yang dilakukan anak usia dini. Anak mereka pun juga belum pernah mengalaminya. Seperti yang disampaikan Mishna et al (2006), adanya pengalaman menjadikan seseorang menjadi lebih sensitif dan menyadari bullying; namun karena SS dan $\mathrm{TOH}$ belum pernah mengalami maka mereka menjadi ragu. Keterlibatan SS di TK IPPA Nurul Haq pun kurang sehingga beliau jarang mengamati bagaimana perilaku dan interaksi anak-anak di sekolah. Namun SS juga berpendapat jika kemungkinan bullying bisa terjadi di TK IPPA Nurul Haq, hanya saja tidak mencolok.

Selanjutnya, walaupun TOH memiliki tingkat pendidikan yang sama dengan SP, namun TOH ragu-ragu akan hal ini. Hal ini justru berbeda dengan pendapat Bili (2021) yang mengemukakan bahwa tingkat pendidikan yang tinggi menjadikan seseorang menjadi lebih menyadari bullying. Perbedaan ini diduga karena prodi SP dan $\mathrm{TOH}$ yang berbeda. $\mathrm{TOH}$ tidak mengambil jurusan pendidikan sehingga tidak mempelajari mengenai psikologi perkembangan dan adanya perbedaan persepsi. Menurut TOH, anak TK belum mengerti mana perbuatan baik dan tidak baik. Anak TK masih memiliki kecenderungan menjadi nakal dan tidak nakal. Apabila anak berbuat nakal maka anak akan melakukannya kepada siapa saja bukan kepada anak tertentu. Pandangan $\mathrm{TOH}$ ini senada dengan anggapan praktisi dan orang tua yang ditemukan Sims-Schouten (2015), bahwa para praktisi dan orang tua menganggap anak kecil tidak mengerti dan tidak mampu membuat penilaian terhadap perilakunya.

Ketiga, empat responden yaitu 3 orang tua (HK, MFH, dan SMN) dan 1 guru (SPD) memandang anak usia tidak bisa melakukan bullying. Tiga orang tua ini juga belum pernah melihat langsung adanya anak usia dini yang melakukan bullying. Selain belum adanya pengalaman, pandangan mereka diduga karena perbedaan persepsi. $\mathrm{HK}, \mathrm{MFH}$, dan SMN memandang masa usia dini identik dengan bermain, perkelahian, menangis, dan mengejek. Oleh karena itu apabila dalam kehidupan sehari-hari ditemukan perkelahian dan kekerasan fisik maupun verbal yang dilakukan anak usia dini maka orang tua tidak akan mendramatisir dan menganggap hal ini bukanlah permasalahan serius. Hal tersebut adalah wajar dan normal, karena tingkah laku anak pada masa usia dini memanglah seperti itu, 
anak berada di bawah umur, dan perilakunya hanyalah bentuk ekspresi yang perlu dikeluarkan. Pandangan HK, MFH, dan SMN senada dengan Sawyer et al (2011) bahwa sebagian besar orang tua menggambarkan intimidasi sebagai masalah ketika konteksnya anak mereka yang menjadi korban. Namun ada sebagian orang tua yang menggambarkan intimidasi sebagai bagian normal dari pertumbuhan. Selain Sawyer et al (2011), Mishna et al (2006) dalam penelitiannya juga menemukan beberapa guru juga menggambarkan bullying sebagai bagian normal dari tahap pertumbuhan dan perkembangan, sehingga penggambaran ini mempengaruhi tanggapan guru dan anggapan bullying sebagai hal yang wajar dan biasa saja. Hal ini senada dengan pandangan HK, MFH, dan SMN.

Pandangan MFH sangat berbeda dengan BAC. MFH dan BAC sama-sama pernah menjadi korban, walaupun terdapat perbedaan yaitu BAC mendapat bullying saat TK; sedangkan MFH saat SMA. MFH tidak akan menganggap kenakalan, perkelahian, dan kekerasan yang dilakukan anak usia dini sebagai permasalahan serius. Tetapi apabila hal ini terjadi saat remaja dan dewasa, maka MFH mengatakan ini perlu ditata karena dampaknya akan tertanam dalam memori. Pandangan MFH ini bisa ditekankan bahwa bullying menjadi permasalahan serius dan perlu dicegah apabila terjadi saat masa remaja dan dewasa. Faktor pengalaman seperti yang disampaikan Mishna et al (2006) tidak berlaku bagi MFH. Hal ini diduga dipengaruhi perbedaan waktu dan si pelaku bullying. BAC menjadi korban saat TK dan bullying juga dilakukan oleh anak usia dini, yang mana waktu dan pelaku sesuai dengan penelitian yang dilakukan peneliti; sedangkan MFH menjadi korban saat SMA dan dilakukan teman SMA-nya. Perbedaan waktu menjadi korban dan si pelaku memperlihatkan bahwa walaupun pengalaman bisa mempengaruhi seseorang menjadi sensitif dan peka terhadap bullying, namun perbedaan "TK dan SMA" menjadikan pandangan dan kesadaran terhadap bullying menjadi berbeda.

Selanjutnya pandangan SMN selain dipengaruhi perbedaan persepsi diduga juga dipengaruhi faktor pendidikan sehingga beliau kekurangan informasi mengenai bullying. Pendidikan terakhir SMN adalah SD, SMN mengaku tidak mengetahui makna bullying. Hal ini sangat berbeda dengan penemuan Bili (2021) yang mana orang tua dengan pendidikan terakhir SD dapat memahami bullying sebagai kenakalan yang dilakukan anak sehingga menyebabkan temannya menangis; sedangkan dalam penelitian ini SMN tidak mengetahui bullying bahkan mengaku belum pernah mendengar istilah bullying. Kallestad \& Olweus (2003) mengemukakan sebuah informasi dapat mempengaruhi cara seseorang dalam merespon permasalahan terutama dalam memahami dan mengambil peran intervensi bullying. SMN sama sekali tidak mengetahui ap aitu bullying, dengan kurangnya informasi tersebut maka SMN menganggap bullying ini sebagai sesuatu yang normal.

Kemudian pandangan SPD yang berbeda dengan empat guru diduga karena perbedaan persepsi. SPD memandang kekerasan yang dilakukan anak-anak di TK IPPA Nurul Haq tidak semata-mata bertujuan membully temannya. Anak usia dini belum mampu melakukan tindakan terencana seperti orang dewasa. Kekerasan tersebut merupakan tindakan spontan karena anak terganggu, tidak nyaman, dan tidak aman sehingga melakukan penyerangan sebagai penyelamatan diri. Sebutan terhadap apa yang dilakukan anak sebagai "tindakan spontan" hampir sama dengan sebutan yang ditemukan Humphrey \& Crisp (2008) bahwa orang tua dan guru memilih menyebut perilaku yang dilakukan anak dengan istilah "perilaku yang tidak pantas" bukan bullying. SPD sangat berbeda dengan ke empat guru lainnya, dimana ke empat guru perempuan ini lebih peka dan menyadari tandatanda bullying pada siswanya. Kemudian Cameron \& Kovac (2016) berpendapat bahwa seorang ayah yang memiliki usia lebih tua dan berpendidikan rendah lebih mengecilkan permasalahan bullying pada anak usia dini. Hal ini sangat berbeda dengan SPD, yang mana SPD adalah guru laki-laki yang berusia 43 tahun dengan pengalaman mengajar sudah 18 tahun dengan tingkat pendidikan lebih tinggi yaitu S1, tetapi SPD memandang tindakan kekerasan yang sering dilakukan anak hanyalah tindakan spontan sebagai bentuk 
penyelamatan diri ketika anak-anak merasa tidak aman dan nyaman sehingga di sini SPD terlihat tidak peka dan kurang menyadari adanya bullying pada siswanya.

\section{Bentuk Bullying yang Terjadi pada Anak Usia Dini Berdasarkan Perspektif Orang Tua dan Guru}

Perspektif orang tua dan guru mengenai kecenderungan perilaku bullying pada anak usia dini tidaklah sama, hanya 1 orang tua (SP) dan 4 guru (SB, BAC, AAA, dan IU) yang memandang bullying bisa dilakukan anak usia dini. Oleh karena itu, bentuk bullying yang dibahas hanya bersumber dari orang tua dan guru yang menemui, meyakini, dan memandang bullying bisa dilakukan anak usia dini. Enam responden lainnya (SS, TOH, HK, MFH, SMN, dan SPD) pernah melihat anak sering melakukan tindakan verbal dan relasional yang menyakiti teman. Namun karena perbedaan persepsi, perilaku tersebut adalah tindakan spontan, wajar, bukan masalah, dan hanya ungkapan ekspresi. Tabel 4 menyajikan berbagai bentuk bullying yang pernah terjadi di TK IPPA Nurul Haq berdasarkan perspektif lima responden yang meyakini bullying dapat dilakukan anak usia dini.

\section{Tabel 4. Bentuk Bullying yang Terjadi di TK IPPA Nurul Haq Berdasarkan Perspektif Orang Tua dan Guru}

\begin{tabular}{ll}
\hline Responden & \multicolumn{1}{c}{ Bentuk Bullying } \\
\hline SP & $\begin{array}{l}\text { Bullying yang pernah ditemui sederhana saja ya, katakanlah anak bermain kemudian } \\
\text { diejek dan menangis itu kan sudah termasuk bullying. }\end{array}$ \\
\hline SB & F dulu sering ditonjok perutnya, terus selama satu minggu tidak berangkat. Ejekan fisik \\
& juga ada seperti ih kamu kok gendut, ih rambutmu keriting. Terus ada juga yang sering \\
bilang 'aku enggak temanan sama kamu'. Ada lagi bullying dalam bentuk makanan, dan ini \\
sudah terjadi 3-4 kali.
\end{tabular}

Berdasarkan tabel 4, terlihat bahwa terdapat tiga macam bullying yang sudah pernah terjadi di TK IPPA Nurul Haq yaitu bullying fisik, verbal, dan relasional. Bullying pertama adalah bullying fisik, tiga guru (SB, BAC, dan IU) menyatakan bullying fisik terjadi dalam bentuk meninju perut, memukul, dan menjegal. Tindakan ini sengaja dilakukan karena perselisihan dan sikap temperamental yang tidak hanya terjadi pada anak laki-laki saja. Dahulu pernah ada anak perempuan yang temperamental juga berani memukul teman laki- 
laki. Temuan ini senada dengan salah satu faktor penyebab bullying yang dikemukakan Olweus (1996) bahwa anak yang bertemperamen aktif cenderung menyelesaikan masalah dengan kepala panas dan lebih agresif. Oleh karena itu, adanya perselisihan disertai temperamen anak yang aktif maka anak memilih menyelesaikannya perselisihan tersebut dengan kekerasan. Selanjutnya, tiga guru (SB, BAC, dan AAA) menyebutkan selain tiga bentuk tersebut, juga terdapat anak yang sering meminta makanan milik teman. Apabila tidak diberikan maka langsung direbut oleh anak yang meminta. Meminta dan merebut makanan, menurut Ehan (2007) adalah pemerasan dan pemerasan juga salah satu dari bullying fisik langsung. Anak-anak yang menjadi korban ini tidak memiliki kuasa untuk menolak sehingga mau tidak mau korban harus memberikan makanan yang dibawa; dan dalam keadaan ini kekuatan sangatlah tidak seimbang.

Selanjutnya bullying kedua yaitu verbal dikemukakan oleh SP, SB, BAC, AAA, dan IU. Bullying verbal yang terjadi yaitu mengejek. Mengejek dilakukan dalam berbagai bentuk seperti mengejek fisik, nama, sifat teman, hasil karya, dan kemampuan. 1) Mengejek fisik, hal ini disampaikan oleh SB, BAC, dan AAA. Ejekan tersebut dilakukan dengan berkata 'ih rambutmu keriting; kamu kok gendut; kamu kurus; kamu jelek' bahkan sampai menyalahkan fisik temannya. 2) Mengejek sifat, ini disampaikan oleh BAC. Ejekan sifat dilakukan teman sekelas kepada satu anak yang pendiam dan susah bergaul. Anak ini selalu duduk di pojokan dan tidak berinteraksi dengan teman sehingga teman sekelasnya sering berkata "itu tho cuma diam, duduk di pojokan". 3) Mengejek hasil karya, hal ini disampaikan IU. Ejekan ini terjadi saat guru meminta anak membuat hasil karya dan menampilkannya. Namun hasil karya tersebut kurang sesuai dengan contoh guru, sehingga ada teman lainnya yang berkata 'eh itu jelek hasil karyamu'. Menurut guru, ejekan ini sering terjadi di kelasnya. Lalu IU juga menyebutkan adanya ejekan yang awalnya dilakukan oleh individu "kamu kok tidak mau sih, ih bodoh bodoh". Namun ejekan berubah menjadi kelompok karena teman lain ikut berkata 'bodoh bodoh'. Menurut White (2018), saat pelaku melakukan bullying verbal maka pelaku sebelumnya sudah mengetahui informasi yang berhubungan dengan kelemahan korban. Di TK IPPA Nurul Haq ejekan ini ditujukan kepada anak yang gendut, pendiam, dipandang jelek, tidak mampu; kesemuanya ini dianggap sebagai kelemahan. Hal ini sejalan dengan White (2018) bahwa kelemahan tersebut seperti ras dan etnis yang berbeda serta kekurangan lainnya yang dijadikan sebagai bahan untuk melakukan bullying verbal. Selanjutnya ejekan ke 4) AAA menyebutkan adanya ejekan nama teman, seperti memanggil "Sri" menjadi "Srintil". Menurut White (2018) pemanggilan nama dengan tujuan menyinggung adalah salah satu tanda dari bullying verbal. Hal ini seperti di TK IPPA Nurul Haq bahwa awalnya panggilan "Srintil" hanya untuk bercanda, namun karena pemanggilan ini sering dilakukan maka anak yang bernama "Sri" menjadi tidak nyaman dan tersinggung sehingga hal ini juga merupakan pembullyan.

Bullying ketiga adalah bullying relasional yang dikemukakan SB dan BAC, berupa pengucilan dan penghasutan. SB sering mendengar anak berkata kepada temannya " $a k u$ enggak teman kamu". Kemudian ketika istirahat ada anak yang melapor kepada BAC bahwa temannya tidak mau bermain dengan dia karena ada teman lain yang menghasut "e enggak usah temanan sama ini". BAC menyampaikan bahwa pengucilan dan penghasutan ini disebabkan karena anak perempuan memiliki kutu di kepalanya, dan ini dianggap "jijik" sehingga anak dikucilkan. Rasa tidak mau bermain karena kutu merupakan ciri unik yang terjadi dalam bullying relasional pada anak usia dini. Sejalan dengan Huang et al (2018) bahwa terdapat ciri unik ketika anak usia dini melakukan bullying relasional yaitu dilakukan secara sederhana dan langsung seperti dengan berkata "aku tidak mau berteman denganmu, kalau kamu tidak mau meminjamkan mainan", tetapi dalam penelitian ini ditemukan karena temannya memiliki kutu di kepalanya sehingga dianggap "jijik". 


\section{Upaya Pencegahan dan Penanganan yang Dilakukan Orang Tua dan Guru Terhadap Bullying pada Anak Usia Dini}

Bullying bukan permasalahan yang dapat dipandang remeh. Hasil penelitian menemukan bahwa bullying sangat merugikan bagi perkembangan fisik, psikologis, dan akademik anak (Goryl et al., 2013; Karatas \& Ozturk, 2011; Kirves \& Sajaniemi, 2012; Swit, 2018). Perlu usaha untuk mencegah, menangani, meminimalisir, dan memperbaiki perilaku anak. Orang tua dan guru memainkan peran penting dalam pencegahan bullying yang mana ketika ini terjadi, orang tua dan guru diharapkan dapat langsung menanganinya (Huang et al., 2018; Mills, 2013). Seperti Saracho (2016), pencegahan dan penanganan tidak hanya untuk menghilangkan bullying, tetapi juga memberi tawaran keterampilan sosial emosional, mendukung pengembangan hubungan sehat, aman, dan penuh perhatian. Para orang tua dan guru di TK IPPA Nurul Haq sudah berusaha melakukan berbagai upaya pencegahan dan penanganan bullying. Pertama, Tabel 5 (lampiran) menyajikan upaya-upaya yang dilakukan orang tua serta guru dalam mencegah bullying.

Meskipun orang tua dan guru telah melakukan berbagai pencegahan, namun tidak menutup kemungkinan bullying masih bisa terjadi. Oleh karena itu, selain pencegahan diperlukan juga upaya penanganan terhadap bullying sehingga dapat diminimalisir dan tidak berkelanjutan. Berbagai upaya penanganan juga dilakukan orang tua dan guru di TK IPPA Nurul Haq. Tabel 6 (lampiran) menyajikan upaya penanganan yang telah dilakukan.

Mayoritas dari upaya-upaya yang sudah dilakukan di TK IPPA Nurul Haq sejalan dengan saran yang diberikan Huston et al (2008) yaitu mendorong pertemanan anak; mengajarkan anak untuk percaya diri dan mengekspresikan dirinya; mencari tahu penyebab bullying terjadi; memberikan pemahaman kepada anak bahwa apa yang dilakukannya tidak baik dan tidak diterima oleh orang lain; meningkatkan pengawasan; dan mendiskusikan mengenai perilaku yang dilakukan anak kepada pihak sekolah sehingga dapat memberikan bantuan untuk membimbing dan mengubah perilaku anak. Kemudian adanya penjelasan melalui penayangan film, yang mana dalam film tersebut berisi konten mengenai perbuatan baik dan perbuatan tidak baik, kemudian anak diberikan kesempatan untuk memberikan komentar, menurut Mills (2013) upaya ini adalah salah satu langkah dalam membantu anak untuk menyadari bahwa orang lain dapat memiliki emosi yang berbeda dengan dirinya. Apa yang dirasakan oleh anak belum tentu sama dengan apa yang dirasakan temannya. Selain itu, kegiatan-kegiatan yang telah diberikan guru seperti yang tertera dalam RPPH dan pada pelaksanaan pembelajaran guru selalu bertanya kepada anak mengenai perasaannya serta menanyakan kabarnya, menurut Mills (2013) ini dapat membantu anak dalam meregulasi emosinya dan mengembangkan keterampilan prososial anak.

Berikutnya, para orang tua dan guru di TK IPPA Nurul Haq juga sudah berusaha terbuka dengan anak-anak. Keterbukaan dilakukan untuk membangun komunikasi yang terbuka antara anak dengan orang tua dan guru. Senada dengan White (2018) perlu dorongan untuk melakukan komunikasi terbuka, karena adanya komunikasi terbuka maka baik orang tua maupun guru dapat mengetahui apa yang sudah terjadi atau dialami oleh anak, sehingga bisa menentukan langkah yang tepat untuk menanganinya. Contohnya, orang tua menanyakan keseharian anak yaitu dengan menanyakan ada kegiatan apa saja, kemudian ada kejadian apa. Guru pun juga bertanya kepada anak ketika menemui anak yang terlihat murung atau menangis. Anak pun juga berani dan secara terbuka menyampaikan apa yang terjadi, yaitu temannya tidak mau bermain dengan dia.

Wolfgang \& Wolfgang (Repo, 2015) menyatakan bahwa ada beberapa reaksi guru dalam menghadapi perilaku tidak baik yang dilakukan oleh anak usia dini di sekolah, salah satunya adalah konsekuensi. Pemberian konsekuensi di TK IPPA Nurul Haq sudah diterapkan oleh para guru. Pemberian konsekuensi dilakukan apabila pemberian nasihat tidak memberikan efek terhadap pengurangan perilaku bullying maupun kekerasan yang dilakukan anak. Konsekuensi ini lebih ke arah yang positif dan tidak menggunakan konsekuensi fisik, seperti menghafalkan materi keagamaan atau materi lainnya yang sudah 
dipelajari di sekolah. Namun ada salah satu guru yang pernah memberikan konsekuensi dengan cara mendiamkan anak untuk sementara waktu, menyendirikan anak di ruangan yang berbeda, dan memanggil orang tua untuk datang ke sekolah. Konsekuensi yang diberikan ini hampir sama dengan konsekuensi yang ditemukan Repo (2015) dalam penelitiannya di Finlandia bahwa guru memberikan konsekuensi seperti bangku penalti, pemberian waktu habis, mengambil makanan penutup, mengancam, memindahkan anak ke kelompok balita, mengisolasi anak dari anak lainnya, dan anak-anak lain diizinkan memutuskan hubungan. Mayoritas bentuk konsekuensi yang diberikan oleh guru perempuan maupun guru laki-laki adalah sama, yaitu tidak memberikan hukuman fisik; karena menurut para guru, hukuman fisik tersebut tidak jauh berbeda dengan bullying dan guru juga tidak ingin jika anak akan selalu mengingat bahwa di sekolah sudah pernah dihukum fisik oleh gurunya.

Pemberian konsekuensi tidak hanya dilakukan oleh guru di sekolah. Orang tua pun juga memberikan konsekuensi terhadap perilaku-perilaku negatif yang dilakukan anak; akan tetapi ditemukan bentuk pemberian konsekuensi yang berbeda antara ibu dengan ayah. SS dan TOH tidak pernah memberikan konsekuensi fisik. Konsekuensi yang diberikan seperti menyuruh anak untuk membaca surat pendek, tidak meminjamkan hp dan laptop kepada anak, serta meminta anak untuk tetap tinggal di rumah. Hal ini sangat berbeda dengan konsekuensi yang diberikan oleh dua orang ayah yaitu SMN dan suami TOH. SMN pernah menyambit anaknya ketika anak melakukan perbuatan yang tidak baik; sedangkan suami $\mathrm{TOH}$ pernah menjewer, menylentik, dan mendorong anaknya ketika perilaku anak dirasa sudah melewati batas. Menurut SMN dan suami TOH, tindakan ini dilakukan bukan karena membenci dan tidak menyayangi anak; tindakan tersebut dilakukan sebagai bentuk ketegasan dan shock terapi untuk anak. Pemberian konsekuensi yang berbeda tersebut memperlihatkan bahwa ibu tidak tega dan tidak sampai memberikan konsekuensi fisik kepada anaknya. Konsekuensi ini diberikan dalam bentuk positif, walaupun ada larangan peminjaman hp dan larangan pergi ke luar rumah namun hal ini dapat memberikan kebaikan untuk anak. Berdasarkan konsekuensi yang diberikan SMN dan suami TOH dapat terlihat bahwa beberapa ayah memiliki rasa tega dalam memberikan konsekuensi fisik kepada anaknya, walaupun pada akhirnya ada perasaan menyesal, namun menurutnya hal ini perlu dilakukan sebagai bentuk ketegasan.

Penelitian ini telah dilaksanakan sesuai prosedur ilmiah. Namun, saat pelaksanaannya, peneliti mengalami keterbatasan yaitu adanya pandemi COVID-19 menyebabkan kegiatan pembelajaran harus dilakukan secara daring. Namun, saat penelitian dilaksanakan, pembelajaran di TK IPPA Nurul Haq dilakukan secara daring dan tatap muka terbatas dengan mendatangkan anak ke sekolah sebanyak 1-3 anak setiap sesinya. Akan tetapi, saat pelaksanaannya hanya 1-2 anak saja yang datang. Observasi saat tatap muka terbatas hanya bisa dilakukan pada bulan Mei saja, karena adanya PPKM yang diterapkan oleh pemerintah. Kemudian, masih banyak siswa baru yang belum mengenal teman sekelasnya; dan dengan jumlah anak yang datang sangat sedikit saat tatap muka terbatas sehingga data yang diperoleh dari observasi kurang mendukung hasil penelitian, dimana hasilnya akan berbeda dengan data yang diperoleh apabila keadaan tidak pandemi.

\section{SIMPULAN}

Orang tua memandang bullying sebagai perbuatan negatif yang memojokkan dan menindas satu pihak sehingga menyebabkan ketidaknyaman, rendah diri, dan kalah. Guru juga mengartikan bullying sebagai perilaku negatif yang dilakukan terus menerus dan sengaja sehingga menyebabkan seseorang yang dibully menjadi tersakiti. Perspektif orang tua dan guru mengenai kecenderungan perilaku bullying pada anak usia dini beragam. Keberagaman dipengaruhi tingkat pendidikan, pengalaman, persepsi, dan kurangnya informasi. Perspektif yang berbeda memberikan pengaruh terhadap kesadaran dan kontribusi mereka dalam mencegah dan menangani bullying. Harapannya, hasil penelitian 
ini dapat menambah informasi dan meningkatkan kesadaran, sehingga dapat menyadari dan turut berperan dalam intervensi bullying.

\section{UCAPAN TERIMA KASIH}

Terima kasih peneliti ucapkan kepada Allah SWT atas kemudahan dan kelancaran yang diberikan-Nya. Peneliti juga mengucapkan terima kasih kepada dosen pembimbing yang telah memberikan bimbingan, orang tua dan guru di TK IPPA Nurul Haq yang sudah berpartisipasi dalam penelitian, dan kedua orang tua yang memberikan doa serta bantuan sehingga peneliti dapat menyelesaikan penelitian dan penulisan artikel. Tak lupa peneliti mengucapkan terima kasih kepada tim Jurnal Obsesi yang telah memberi saran, sehingga artikel menjadi lebih baik dan semoga dapat memberikan manfaat bagi para pembaca.

\section{DAFTAR PUSTAKA}

Bili, F. G. (2021). Perspektif Orang Tua Tentang Perilaku Bullying Anak TK : ditinjau dari Tingkat Pendidikan. 5(2), 1644-1654. https://doi.org/10.31004/obsesi.v5i2.939

Cameron, D. L., \& Kovac, V. B. (2016). An examination of parents' and preschool workers' perspectives on bullying in preschool. Early Child Development and Care, 186(12), 19611971. https:// doi.org/10.1080/03004430.2016.1138290

DeVooght, Kerry M.S.W.; Daily, Sarah Ph.D.; Darling-Churchill, Kristin M.P.P.; Temkin, D. P. D. ., \& Novak, M. B. . (2015). Bullies in the Block Area. Child Trends, August. http://www.childtrends.org/wp-content/uploads/2015/08/201531BulliesBlockArea.pdf

Dey Putri, L. A., Yetti, E., \& Hartati, S. (2020). Pengaruh Keterlibatan Orangtua dan Regulasi Diri terhadap Perilaku Bullying Anak Usia Dini. Jurnal Obsesi : Jurnal Pendidikan Anak Usia Dini, 4(2), 715. https://doi.org/10.31004/obsesi.v4i2.438

Douvlos, C. (2019). Students ' essays bullying in preschool children early forms of aggressive behaviour. Psychological Thought, 12(1), 131-142. https://doi.org/10.5964/psyct.v12i1.284

Ehan.M.Pd, D. (2007). Bullying Dalam Pendidikan oleh: Dra. Ehan.M.Pd. Bullying Dalam Pendidikan, 1-21.

Goryl, O., Neilsen-Hewett, C., \& Sweller, N. (2013). Teacher education, teaching experience and bullying policies: Links with early childhood teachers' perceptions and attitudes to bullying. Australian Journal of Early Childhood, 38(2), 32-40. https:// doi.org/10.1177/183693911303800205

Hartati, S., Safitri, D., Marini, A., \& Wahyudi, A. (2020). Bullying Behavior in Early Childhood: Study at Early Childhood Education Institution in East Jakarta in Indonesia. Talent Development \& Excellence, 12(1), 55-63.

Huang, H., Liu, Y., \& Chen, Y. (2018). Preservice Preschool Teachers ' Responses to Bullying Scenarios: The Roles of Years of Study and Empathy. 9(February), 1-13. https://doi.org/10.3389/fpsyg.2018.00175

Humphrey, G., \& Crisp, B. R. (2008). Bullying affects us too: Parental responses to bullying at kindergarten. Australian Journal of Early Childhood, 33(1), 45-49. https://doi.org/10.1177/183693910803300108

Humphrey, L. (2013). Preschool Bullying: Does it Exist, What Does it Look Like, and What Can be Done?

Huston, B. J., Sciences, C., \& Bailey, S. J. (2008). Children and Bullying: A Guide for Parents MontGuide.

Jansen, P. W., Verlinden, M., Berkel, A. D. Van, Mieloo, C., Van Der Ende, J., Veenstra, R., Verhulst, F. C., Jansen, W., \& Tiemeier, H. (2012). Prevalence of bullying and victimization among children in early elementary school: Do family and school neighbourhood socioeconomic status matter? BMC Public Health, 12(1), 1-10. https://doi.org/10.1186/1471-2458-12-494 
Karatas, H., \& Ozturk, C. (2011). Relationship between bullying and health problems in primary school children. Asian Nursing Research, 5(2), 81-87. https://doi.org/10.1016/S19761317(11)60016-9

Kirves, L., \& Sajaniemi, N. (2012). Early Child Development and Care Bullying in early educational settings. January 2015, 37-41. https:// doi.org/10.1080/03004430.2011.646724

Lee, S. (2020). Kindergarten Teachers ' Perspectives on Young Children ' s Bullying Roles in Relation to Dominance and Peer Relationships: A Short - Term Longitudinal Approach in South Korea. https:// doi.org/10.3390/ijerph17051734

Mahriza, R., Rahmah, M., \& Santi, N. E. (2020). Stop Bullying: Analisis Kesadaran dan Tindakan Preventif Guru pada Anak Pra Sekolah. Jurnal Obsesi : Jurnal Pendidikan Anak Usia Dini, 5(1), 891-899. https://doi.org/10.31004/obsesi.v5i1.739

Miles, M. B., Huberman, A. M., \& Saldana, J. (2014). Qualitative data analysis: a method sourcebook edition 3. United States of America: SAGE Publications, Inc.

Mills, H. (2013). Bullying and the early childhood classroom. 36(4), 2009-2011.

Mishna, F., Pepler, D., \& Wiener, J. (2006). Factors associated with perceptions and responses to bullying situations by children, parents, teachers, and principals. Victims and Offenders, 1(3), 255-288. https:// doi.org/10.1080/15564880600626163

Olweus, D. (1994). Annotation: Bullying at School : Basic Facts and Effects of a School Based Intervention Program. 35(7), 1171-1190. https://doi.org/10.1111/j.14697610.1994.tb01229.x

OLWEUS, D. (1996). Bullying at School: Knowledge Base and an Effective Intervention Program. Annals of the New York Academy of Sciences, 794(1 Understanding), 265-276. https://doi.org/10.1111/j.1749-6632.1996.tb32527.x

Rahayu, P., Rasyid, H., Puspitasari, C. A., \& Islamiyah, R. (2020). The Role of Teachers and Parents in Preventing Bullying in Early Childhood Education. 421(Icalc 2019), 359-362. https://doi.org/10.2991/assehr.k.200323.043

Repo, L. (2015). Bullying and its prevention in early childhood education (Issue June).

Reunamo, J., Kalliomaa, M., Repo, L., Salminen, E., Lee, H. C., \& Wang, L. C. (2015). Children's strategies in addressing bullying situations in day care and preschool. Early Child Development and Care, 185(6), 952-967. https://doi.org/10.1080/03004430.2014.973871

Saracho, O. N. (2016). Bullying Prevention Strategies in Early Childhood Education. Early Childhood Education Journal. https:// doi.org/10.1007/s10643-016-0793-y

Sawyer, J. L., Mishna, F., Pepler, D., \& Wiener, J. (2011). The missing voice: Parents' perspectives of bullying. Children and Youth Services Review, 33(10), 1795-1803. https://doi.org/10.1016/j.childyouth.2011.05.010

Sims-Schouten, W. (2015). Bullying in early childhood and the construction of young children as premoral agents: implications for practice. Pastoral Care in Education, 33(4), 234-245. https://doi.org/10.1080/02643944.2015.1094121

Smith, P. K. (2019). How Does Individualism-Collectivism Relate to Bullying Victimisation ? 3-13. https://doi.org/10.1007/s42380-018-0005-y

Storey, K., \& Slaby, R. (2013). Eyes on Bullying in Early Childhood. 1-66. http://www.eyesonbullying.org/pdfs/toolkit.pdf

Swit, C. S. (2018). Early childhood educators ' and parents ' perceptions of bullying in preschool. 47(3), 19-27.

Vlachou, M., Andreou, E., \& Botsoglou, K. (2014). Bullying / Victimization in Preschool Children. Conference Paper, October.

Vlachou, M., Botsoglou, K., \& Andreou, E. (2013). Assessing Bully/Victim Problems in Preschool Children: A Multimethod Approach. Journal of Criminology, 2013, 1-8. https://doi.org/10.1155/2013/301658

White, B. J. (2018). Preschoolers aggressive behavior toward others is it child-play? Is it bullying? Dissertation Abstracts International Section A: Humanities and Social Sciences, 79(10A(E)), No-Specified.

Zakiyah, E. Z., Humaedi, S., \& Santoso, M. B. (2017). Faktor Yang Mempengaruhi Remaja Dalam Melakukan Bullying. Prosiding Penelitian Dan Pengabdian Kepada Masyarakat, 4(2), 324330. https://doi.org/10.24198/jppm.v4i2.14352 
Perspektif Orang Tua dan Guru Mengenai Bullying Pada Anak Usia Dini di Taman Kanak-kanak DOI: $10.31004 /$ obsesi.v6i4.2313

Zimmerman, F. J., Glew, G. M., Christakis, D. A., \& Katon, W. (2005). Early cognitive stimulation, emotional support, and television watching as predictors of subsequent bullying among grade-school children. Archives of Pediatrics and Adolescent Medicine, 159(4), 384-388. https://doi.org/10.1001/archpedi.159.4.384 


\section{Lampiran 1}

Tabel 5. Upaya Orang Tua dan Guru dalam Mencegah Bullying pada Anak Usia Dini

\begin{tabular}{|c|c|}
\hline Responden & Upaya Pencegahan yang Dilakukan \\
\hline \multicolumn{2}{|l|}{ Orang Tua } \\
\hline HK & $\begin{array}{l}\text { Anak dinasihati kalau main sama teman enggak boleh nakalin teman, karena } \\
\text { kalau nakali maka temannya tidak mau bermain denganmu. Jadi kamu enggak } \\
\text { akan punya teman. Tapi kalau posisinya anak saya itu benar ya dia harus berani } \\
\text { ketika dinakalin. }\end{array}$ \\
\hline SS & $\begin{array}{l}\text { Memberitahukan ke anak itu tindakan yang tidak tepat dan juga kalau bermain } \\
\text { dengan cara yang baik, tidak saling mengejek. Lalu korbannya diajarkan percaya } \\
\text { diri, sehingga ketika itu terjadi maka dia bisa menghindar. Guru pun juga harus } \\
\text { memberikan suri tauladan yang baik }\end{array}$ \\
\hline SP & $\begin{array}{l}\text { Saya yakin di sekolah pasti ada tata tertib, tata tertib dibuat salah satunya untuk } \\
\text { mencegah bullying atau kekerasan. Tetapi sebagai orang tua, kita perlu } \\
\text { memberikan pengertian pada anak. Sebisa mungkin orang tua terbuka dengan } \\
\text { anak sehingga anak bisa mudah menceritakan segala yang dialaminya kepada } \\
\text { orang tua. Ketika anak bercerita, saat itu orang tua memberikan masukan dan } \\
\text { nasihat. Selanjutnya, perlu juga mengadakan komunikasi dengan guru mengenai } \\
\text { bagaimana perkembangan anak kalau berinteraksi di sekolah. Kemudian kita juga } \\
\text { tahu kalau salah satu penyebab bullying adalah media. Jadi di sini kita perlu } \\
\text { membatasi aktivitas anak dengan dunia teknologi dan internet. Kita harus lebih } \\
\text { bijaksana mendampingi anak ketika mereka terpaksa harus menggunakan } \\
\text { teknologi. }\end{array}$ \\
\hline MFH & $\begin{array}{l}\text { Saya itu kalau untuk tontonan harus dipilihkan tontonan yang banyak dialog dan } \\
\text { edukatif. Kalau tontonan yang ada kekerasannya atau kalimat-kalimat ekstrimnya } \\
\text { jelas saya larang. Lalu kita harus mengarahkan anak ketika mereka mencari teman, } \\
\text { carilah teman yang baik dari segi bicaranya dan perilakunya. }\end{array}$ \\
\hline $\mathrm{TOH}$ & $\begin{array}{l}\text { Kami memang tidak banyak memberi akses hp ke anak, mereka bisa mainan hp } \\
\text { dan laptop ketika saya pulang kerja dan saya menunggu ketika anak bermain } \\
\text { game. Kalau ada game yang di dalamnya ada tusuk menusuk, senjata, pukulan itu } \\
\text { langsung tidak saya perbolehkan karena saya takut dia akan mencontoh apa yang } \\
\text { dilihat tersebut kepada temannya. Selain itu, kita juga cuma bisa memberi tahu aja } \\
\text { ke anak, kasih nasihat. Ketika dinakali teman ya kamu jangan diam saja, harus } \\
\text { berani kalau perlu ya pukul. Kemudian anak itu juga setiap harinya juga saya } \\
\text { tanya tentang kegiatannya apa di sekolah, ada kejadian apa di sekolah. }\end{array}$ \\
\hline SMN & $\begin{array}{l}\text { Jelas kita perlu memberikan nasihat dan mengajarkan anak agar sopan berperilaku } \\
\text { dan berbicara kepada siapa pun. Sebagai orang tua juga saya harus menjadi } \\
\text { tauladannya anak, kalau perilaku orang tua jelek ya pasti anak akan ikut jelek. } \\
\text { Kita juga perlu tahu karakter anak kita seperti apa, jadi kalau nanti terlihat } \\
\text { berbeda kita bisa menanyakan apa yang terjadi, kenapa seperti itu. }\end{array}$ \\
\hline \multicolumn{2}{|l|}{ Guru } \\
\hline SB & $\begin{array}{l}\text { Pertama kita tanamkan rasa sayang kepada sesama teman, seperti dalam hadist } \\
\text { kasih sayang. Kedua, kita meningkatkan pengawasan saat anak-anak bermain dn } \\
\text { istirahat. Ketiga, secara kontinue mengingatkan agar anak-anak menjaga anggota } \\
\text { tubuhnya dari hal-hal yang dapat menyakiti teman. Lalu rasa percaya diri anak } \\
\text { juga perlu dikembangkan misalnya dengan kegiatan yang mendorong anak untuk } \\
\text { kerjasama dengan teman, karena kalau anak yang minder dan pemalu itu beresiko } \\
\text { sekali ditindas temannya. }\end{array}$ \\
\hline BAC & $\begin{array}{l}\text { Kita melakukan pengawasan, jadi gurunya diblok di beberapa tempat yang } \\
\text { menjadi titik rawan. Lalu kita juga memberi nasihat untuk anak, nasihat disertai } \\
\text { penjelasan tentang dampak yang ditimbulkan. Untuk kasus anak yang pendiam, } \\
\text { itu kita mengantisipasinya dengan cara memotivasi anak agar berani dan mau }\end{array}$ \\
\hline
\end{tabular}




\begin{tabular}{ll}
\hline Responden & \multicolumn{1}{c}{ Upaya Pencegahan yang Dilakukan } \\
\hline AAA & bergaul dengan teman, saat kegiatan juga dilakukan berkelompok. \\
& Pencegahan secara tidak langsung sudah diterapkan dengan setiap hari memberi \\
& contoh yang baik, menasihati sambil memberi penjelasan kepada anak tentang \\
& perbuatan baik, tidak baik, dan dampak yang ditimbulkan. Penjelasan dilakukan \\
& melalui cerita dan contoh langsung. Lalu anak dilatih agar berani dalam arti berani \\
& melawan, menghindar, dan tidak meladeni teman yang menyakiti. Selain berani \\
& juga rasa percaya diri perlu dikembangkan, dilakukan dengan meminta anak maju \\
& ke depan. Kalau dalam kegiatan pembelajaran itu dengan kerja kelompok, dari \\
& kerja kelompok anak akan berkerjasama dan bisa menghargai teman. Tak lupa \\
& guru juga harus adil dalam memberikan kasih sayang dan perhatian untuk anak- \\
anak. & Sekolah kan punya tata tertib ya, jadi di dalam tata tertib itu anak diharapkan \\
& untuk bisa menjaga keamanan dan ketertiban di sekolah. Kemudian guru \\
& memberikan penjelasan tentang perbuatan baik dan tidak baik yang dilakukan \\
& melalui cerita, film, maupun kartu gambar. Selain penjelasan, anak juga dinasihati \\
tentang apa yang sudah dilakukannya serta dampaknya; sehingga dengan nasihat & \\
ini insyaAllah nanti bisa memunculkan empati pada diri anak. \\
\hline IU \\
Pencegahan ya pengawasan jelas harus dilakukan di setiap tempat ketika anak- \\
anak belajar di sekolah, ada guru yang berada di pos-pos tertentu untuk \\
mengawasi. Kedua, ketika kegiatan guru memisahkan anak yang diindikasi sering \\
melakukan kekerasan sehingga anak ini tidak satu kelompok dengan anak yang \\
menjadi korban. Ketiga, penyampaian tentang perbuatan benar dan salah baik \\
secara langsung maupun melalui film dan cerita. Film dan cerita yang diambil \\
adalah film dan cerita yang memiliki nilai budi pekerti, akhlaq, dan hal-hal baik \\
yang bisa diteladani anak. Kemudian kita juga menyampaikan kepada orang tua \\
mengenai pertemanan anak di sekolah sehingga orang tua juga ikut memantau. \\
\hline SPD
\end{tabular}

Tabel 6. Upaya Orang Tua dan Guru dalam Menangani Bullying pada Anak Usia Dini

\begin{tabular}{ll}
\hline Responden & \multicolumn{1}{c}{ Upaya Penanganan yang Dilakukan } \\
\hline Orang Tua & \multicolumn{1}{c}{} \\
\hline HK & $\begin{array}{l}\text { Dinasihati secara halus si pelaku tadi sama diberi sedikit ancaman seperti nanti } \\
\text { kalau nakal saya bilangin kakek, intinya orang yang ditakuti anak. Lalu untuk } \\
\text { anak saya sendiri kalau dia berbuat kekerasan ya saya hukum, tapi bukan } \\
\text { hukuman fisik melainkan saya suruh berdiri di sudut ruangan rumah. }\end{array}$ \\
\hline SS & $\begin{array}{l}\text { Kalau bullying terjadi di sekolah janganlah takut, bisa minta tolong ya semacam } \\
\text { bicara sama guru. Lalu kita bisa sharing sama guru dan bisa mempertemukan wali } \\
\text { dari siswa itu untuk menginformasikan apa yang sudah dilakukan anak untuk } \\
\text { mencegah supaya nanti tidak terlanjur. Anak yang melakukan bullying juga } \\
\text { mestinya diberikan punishment, misalnya baca surat pendek. Sebelumnya juga } \\
\text { anak diminta untuk minta maaf. }\end{array}$ \\
\hline SP & $\begin{array}{l}\text { Ya kita harus memberikan pengertian kepada anak dengan lebih. Artinya kalau } \\
\text { sudah terjadi ya kita beri pengertian, tidak boleh melakukan itu. Kemudian nanti } \\
\text { kita juga cerita dampaknya apa, tetapi perlu waktu yang tepat untuk melakukan } \\
\text { hal ini. }\end{array}$ \\
\hline Kalau terlanjur ya pendampingan orang tua, dalam arti orang tua mendampingi \\
anak agar percaya diri lagi dan tidak minder. Caranya dengan menonjolkan \\
kemampuan anak, beri pujian dengan kalimat yang sederhana.
\end{tabular}




\begin{tabular}{|c|c|}
\hline & $\begin{array}{l}\text { dilakukan untuk shock terapi. Kalau saya, konsekuensi itu saya lebih banyak bicara } \\
\text { dan tidak diperbolehkan mainan hp, tapi tangan saya tidak pernah maju. }\end{array}$ \\
\hline SMN & $\begin{array}{l}\text { Saya itu orangnya tegas, jadi kalau sampai anak saya melakukan tindakan yang } \\
\text { tidak baik itu pasti saya kasih hukuman dulu. Saya itu pernah menyambit anak, } \\
\text { sebenarnya ya saya menyesal. Tetapi hal ini perlu dilakukan agar orang tua itu } \\
\text { terlihat tegas dan bisa memberikan efek jera untuk anak. Lalu orang tua tetap } \\
\text { harus merangkul anak, setelah saya keras maka di hari berikutnya saya memberi } \\
\text { masukan-masukan lagi untuk anak. }\end{array}$ \\
\hline \multicolumn{2}{|r|}{ ( } \\
\hline SB & $\begin{array}{l}\text { Mencari penyebab masalah dulu dari sisi pelaku dan korban, terus memecahkan } \\
\text { masalah dan yang terakhir itu saling meminta maaf. Kita juga memberi nasihat } \\
\text { kepada pelaku untuk tidak mengulangi perbuatannya selain itu juga menasehati } \\
\text { anak agar mencoba untuk mengelola emosinya. Nanti kalau perbuatannya masih } \\
\text { diulangi biasanya kita beri sanksi misalnya hafalan Surah Al-Fatihah, praktik } \\
\text { wudhu, dan mendatangkan orang tua ke sekolah untuk bersama-sama mencari } \\
\text { solusi. }\end{array}$ \\
\hline BAC & $\begin{array}{l}\text { Kalau sudah terjadi ya tetap menasihati, mengajarkan anak untuk saling } \\
\text { menyayangi, lalu guru juga perlu meningkatkan pengawasan. Kerjasama dengan } \\
\text { orang tua juga kita lakukan dengan melaporkan apa yang terjadi kepada orang } \\
\text { tua, agar orang tua di rumah juga bisa membantu memberikan motivasi dan } \\
\text { pengertian. Guru pernah memberikan hukuman kepada anak, tetapi hukumannya } \\
\text { dilakukan dengan anak harus membaca ayat ini, surat ini, melafalkan tulisan ini. }\end{array}$ \\
\hline AAA & $\begin{array}{l}\text { Kalau terlanjur terjadi ya anak-anak yang terlibat bullying dipertemukan untuk } \\
\text { meminta maaf. Saat itu anak juga diberi pengertian bahwa bullying bukan } \\
\text { perbuatan yang baik lalu menyebutkan akibatnya. Meningkatkan pengawasan } \\
\text { juga dilakukan pada anak dengan cara guru diplotkan ke beberapa tempat untuk } \\
\text { memudahkan pengawasan. Lalu, sekolah ini kan sekolah Islam ya jadi kalau ada } \\
\text { anak yang berbuat tidak baik itu juga diberi hukuman, tetapi bukan hukuman } \\
\text { fisik; melainkan menghafal surat pendek, hadist, Asmaul Husna, atau perintah } \\
\text { untuk berbuat baik. }\end{array}$ \\
\hline IU & $\begin{array}{l}\text { Kalau sudah terjadi, penanganannya tergantung tingkatannya. Pertama pasti } \\
\text { pertolongan pertama dulu pada anak. Lalu kita jelaskan dulu perbuatanmu tadi } \\
\text { salah. Kalau anak ini sudah tahu perbuatannya, namun diulangi terus menerus } \\
\text { maka anak perlu diberikan sanksi, sanksinya yang ringan dahulu. Sanksinya bisa } \\
\text { berupa mendiamkan anak sementara waktu, menyuruh anak maju ke depan, } \\
\text { meminta anak menghafal, dan menyendirikan anak di ruangan berbeda. Kalau } \\
\text { sanksi ringan tetapi anak masih melakukannya maka orang tua perlu dipanggil ke } \\
\text { sekolah supaya orang tua bisa membantu. Lalu untuk korbannya harus diberikan } \\
\text { penguatan agar tetap semangat dan tidak rendah diri. Kemudian juga diajarkan } \\
\text { agar mampu untuk mengeluarkan atau melaporkan kepada gurunya tentang } \\
\text { perasaannya dan harus bersikap asertif. }\end{array}$ \\
\hline SPD & $\begin{array}{l}\text { Penanganannya memanggil anak yang terlibat dahulu. Kemudian kita tanya satu- } \\
\text { satu, kita berikan kesempatan untuk saling bercerita. Setelah selesai, baru kita } \\
\text { sentuh hatinya yaitu dengan cara kita bicara semampunya dari hati ke hati } \\
\text { kemudian kita minta mereka untuk saling meminta maaf. Sedangkan korban, kita } \\
\text { berikan support untuk membesarkan hatinya, agar anak tidak merasa malu. Lalu } \\
\text { konsekuensi terhadap perilaku anak itu juga ada. Biasanya anak kita suruh untuk } \\
\text { menghafalkan surat pendek, ayat-ayat pilihan, atau doa. }\end{array}$ \\
\hline
\end{tabular}

